\title{
The Bioaccumulation and Migration of Inorganic Mercury and Methylmercury in the Rice Plants
}

\author{
Daiwen Zhu ${ }^{1}$, Jichang Han ${ }^{1 *}$, Shizhang $\mathrm{Wu}^{2}$ \\ ${ }^{1}$ Institute of Land Engineering and Technology, Shaanxi Provincial Land Engineering Construction Group Co., \\ Ltd. Key Laboratory of Degraded and Unused Land Consolidation Engineering, the Ministry of Land and Resources, \\ Shaanxi Provincial Land Consolidation Engineering Technology Research Center \\ Xi'an city, Shaanxi province, China \\ ${ }^{2}$ PowerChina Northwest Engineering Corporation Limited. Xi'an city, Shaanxi province, China
}

Received: 4 May 2016

Accepted: 13 February 2017

\begin{abstract}
In the present study, $\left(\mathrm{NH}_{4}\right)_{2} \mathrm{~S}_{2} \mathrm{O}_{3}$ extraction methods were applied to assess bioaccumulation of methylmercury ( $\mathrm{MeHg}$ ) in rice grains, and inorganic mercury $(\mathrm{IHg})$ concentrations in rice leaves were analyzed during the rice growing time to access the bioaccumulation of $\mathrm{IHg}$ in rice leaves. The results show that the IHg concentrations in leaves increased in the rice harvest stage, indicating that the limit or no $\mathrm{IHg}$ was migrated to the rice grain. Also, the Hg-contaminated leaves may potentially cause the input of "new $\mathrm{Hg}$ ' into soil, leading to a vicious $\mathrm{Hg}$ pollution cycle in a rice paddy system. Our results indicated that $\mathrm{MeHg}$ concentrations in leaves could not be used to predict the MeHg bioaccumulation in rice grain. Meanwhile, $\mathrm{MeHg}$ transferred capability from soil to leaves decreased with time, which could be the common effect of the decreased soil $\mathrm{MeHg}$ bioavailability and translocation of $\mathrm{MeHg}$ from leaves to rice grains.
\end{abstract}

Keywords: methylmercury, inorganic mercury, bioaccumulation, rice leaves

\section{Introduction}

Mercury $(\mathrm{Hg})$ is a global pollutant that can be methylated to methylmercury $(\mathrm{MeHg})$, which is of great concern due to its biomagnification through the food chain. Recently, there has been an increasing awareness of food safety problems resulting from $\mathrm{Hg}$-contaminated farmland [1-2]. It has been reported that extremely high concentrations of total mercury (THg, e.g., 330 -790,000 ng/g) and MeHg (e.g., 0.13-23 ng/g) have been

*e-mail:wsz99108@gmail.com found in contaminated farmland soils [3-4], and rice plants grown in $\mathrm{Hg}$-contaminated areas could accumulate high levels of $\mathrm{MeHg}$ in the grain [5], leading to $\mathrm{MeHg}$ exposure for people. This could be because flooded conditions in $\mathrm{Hg}$-polluted rice paddy fields favor $\mathrm{MeHg}$ yield and could possibly result in extremely high $\mathrm{MeHg}$ bioaccumulation in rice plants [6]. Considering that rice is a staple food in Asia, consumption of rice could be an important $\mathrm{MeHg}$ exposure route for residents in some mercury-polluted areas [7]. Therefore, it is of great importance to explore the underlying mechanisms of bioaccumulation of inorganic mercury ( $\mathrm{IHg}$ ) and $\mathrm{MeHg}$ in the rice plants, thus helping to predict the bioaccumulation and risk of $\mathrm{Hg}$ in 
rice plants.

$\mathrm{MeHg}$ uptake from soil is considered the major pathway of $\mathrm{MeHg}$ accumulation in rice plants [8]. $\mathrm{MeHg}$ in soil was first absorbed by roots and then translocated to the above-ground parts (leaves and stalk, [9]). However, $\mathrm{IHg}$ accumulated in rice plants could mainly come from the atmosphere through leaf uptake, but not from soil [1011], because the root surface, acting as IHg barrier, could inhibit the translocation of $\mathrm{IHg}$ through the root system to the aboveground parts, but could not inhibit $\mathrm{MeHg}$ transfer [12]. Meanwhile, recently rice leaves and stalk burial is being encouraged all over the world as an economical and environmentally friendly method to get rid of rice residuals. However, the $\mathrm{Hg}$-contaminated leaves may potentially cause $\mathrm{Hg}$ pollution in soil, resulting in the high $\mathrm{MeHg}$ concentrations in rice plants, which cause a vicious $\mathrm{Hg}$ pollution cycle in the rice paddy system. Therefore, a better understanding of different bioaccumulation of $\mathrm{MeHg}$ and $\mathrm{IHg}$ in rice plants and leaves could be critical in risk assessment of human mercury exposure.

To our knowledge, the $\mathrm{Hg}$ bioaccumulation in the rice plants is generally believed to be a dynamic process of uptake-translocation-accumulation [13]. However, the mechanism of $\mathrm{Hg}$ migration within the rice plant and the difference between the $\mathrm{MeHg}$ and $\mathrm{IHg}$ in the translocation mechanism was unclear. Besides, lots of research mainly focused on $\mathrm{MeHg}$ accumulation in the rice grain [14-15], given its potential $\mathrm{MeHg}$ exposure to humans. Limited studies have focused on $\mathrm{Hg}$ pollution in rice leaves. Since after harvest the rice leaves would be buried in soils in order to increase soil fertility in rice paddy fields [16]. Consequently, the Hg-contaminated rice leaves may potentially lead to $\mathrm{Hg}$ pollution in soil, further contaminating the rice plants in the second year. Therefore, studying $\mathrm{MeHg}$ and $\mathrm{IHg}$ accumulation in rice leaves was considered necessary.

In the present study, we analyzed farmland soils amended with $\mathrm{IHg}$ that were planted with rice plants as well as $\mathrm{IHg}$ and $\mathrm{MeHg}$ concentrations in rice leaves during the rice growing time to assess its bioaccumulation in leaves. Meanwhile, the $\left(\mathrm{NH}_{4}\right)_{2} \mathrm{~S}_{2} \mathrm{O}_{3}$ chemical extraction method was used in this experiment to evaluate the potential bioaccumulation of $\mathrm{MeHg}$ in rice grains [17]. The MeHg transfer capability from soil to rice plants was also investigated. Our main objectives were to investigate the bioaccumulation and migration of $\mathrm{IHg}$ and $\mathrm{MeHg}$ mechanisms in rice leaves and plants.

\section{Materials and Methods}

Soil samples were collected from Heilongjiang (HLJ), Sichuan (SC), Shanxi (SX), Hubei (HB), Jiangxi (JX), Henan (HN), Jiangsu (JS), and Guizhou (GZ) provinces in China, dried, ground, and sieved through a $150 \mu \mathrm{m}$ mesh.

A total of 24 pots (three replicates for each treatment) in eight treatments (eight soils) were used. For each pot, $3 \mathrm{~kg}$ soil was amended with $\mathrm{Hg}\left(5 \mathrm{mg} / \mathrm{kg}\right.$, as $\mathrm{HgCl}_{2}$ solution) at the start of the experiment (day 0, [18]). Soil samples were placed into pots $(2.8 \mathrm{~kg}$ soil $/$ pot $)$ and equilibrated for 20 days under flooded conditions. Seeds of indica Wufengyou2168 (indica WFY2168) were germinated in soil for one month in a growth chamber prior to transplantation into pots (two seeds per pot). After the seeds were transplanted into soil, granulated fertilizer $\left(0.32 \mathrm{gkg}^{-1} \mathrm{Ca}\left(\mathrm{HPO}_{4}\right)_{2} \cdot \mathrm{H}_{2} \mathrm{O}, 0.18 \mathrm{~g} \mathrm{~kg}^{-1} \mathrm{KCl}\right.$, and $0.21 \mathrm{~g} \mathrm{~kg}^{-1}$ $\left.\mathrm{CO}\left(\mathrm{NH}_{2}\right)_{2}\right)$ [19] was added as basal application, which was repeated on days 60 (panicle stage) and 90 (flowering stage) to ensure adequate nutrition for the growth of rice seedlings. And plants were grown in the greenhouse from 1 July to 24 October 2013 (115d) at ambient temperature $\left(15-38^{\circ} \mathrm{C}\right)$. The flooded condition was maintained with deionized water ( $3 \mathrm{~cm}$ above soil surface) during the entire rice growth period.

Soils and plant leaves were sampled at day 54 (i.e., panicle initiation stage), day 77 (i.e., heading stage), day 105 (i.e., milk-ripe stage) and day 132 (i.e., harvest stage) of the growing period, respectively. Soil samples were sampled in the soil surface $(1-11 \mathrm{~cm})$ and then collected into polypropylene centrifuge tubes, immediately vacuumpacked to remove oxygen in situ, and transferred to the laboratory in an ice box within $3 \mathrm{~h}$. The leaf samples with a composition of two leaves per pot were cut at the bottom of the rice plant each time and then were cleaned first with tap water to remove the remaining soil, and cysteine solution $(8 \mathrm{~mm} / \mathrm{L})$ were subsequently used to remove the mercury adsorbed on the surface of leaves [20]. After that, leaf samples were rinsed thoroughly in deionized water and freeze-dried. Then leaves were ground into fine powders by an IKA basic analytical mill (IKA A11, Germany) and used for mercury determination (described below).

The soil samples were centrifuged at 3,000 rpm for $30 \mathrm{~min}$. to remove pore water and amended with $\left(\mathrm{NH}_{4}\right)_{2} \mathrm{~S}_{2} \mathrm{O}_{3}$ solution $(0.0135 \mathrm{~mol} / \mathrm{L})$ at a $1: 2$ ratio, and then were rotated at $250 \mathrm{rpm}$ per minute overnight in a shaker [17]. The mixtures were centrifuged at 3,000 rpm for $30 \mathrm{~min}$. and the supernatants were filtered. $\mathrm{HCl}$ was added to the supernatant to obtain $0.5 \% \mathrm{HCl}$ before determining $\mathrm{MeHg}$ [7]. All the process was employed in the anaerobic chamber in the dark, and the extractants were prepared with deoxygenated water to avoid soil oxidation. Meanwhile, the soil property including $\mathrm{pH}$ (HACH HQ30d) as well as particulate organic carbon (POC) levels (vario TOC cube, Elementar, Germany) in the soils were determined.

Total Hg was determined by a DMA- 80 direct mercury analyzer (Milestone, Italy). $\mathrm{MeHg}$ concentrations were analyzed by an automatic Brooks Rand model III MeHg analyzer (CVAFS, Brooks Rand, USA) according to EPA method 1630. The soil, liquid, and plant samples were digested using $\mathrm{KOH}-m e t h a n o l$ solution, and incubated in the shaker for four hours at $60^{\circ} \mathrm{C}$ for $\mathrm{MeHg}$ analysis [2122]. The minimum detection levels for $\mathrm{THg}$ and $\mathrm{MeHg}$ is $0.2 \mathrm{ng} / \mathrm{g}$ and $0.002 \mathrm{ng} / \mathrm{L}$, respectively. The recoveries of the standard samples for MeHg (ERM-cc58) and for THg (soil standard GSS-9 and mercury standard solutions) 
were between $80-120 \%$ and $85-110 \%$. IHg concentrations of leaves were calculated by subtracting the $\mathrm{MeHg}$ concentrations from the $\mathrm{THg}$ concentrations.

Background mercury levels in all chemicals were extremely low. Polypropylene centrifuge tubes were used in this study. And the tubes were considered relatively mercury-free because mercury levels in $2 \%$ nitric acid after rinsing the tubes were below detection limits. Quality control was assured by method/reagent blanks, matrix spikes, and certified reference materials as well as duplicate analysis. Any change of mercury extraction by $\left(\mathrm{NH}_{4}\right)_{2} \mathrm{~S}_{2} \mathrm{O}_{3}$, or mercury concentrations in soils and in leaves was tested using one-way analysis of variance (ANOVA).

\section{Results and Discussion}

\section{Properties of Different Soils and Concentrations of MeHg in Soils}

Background $\mathrm{MeHg}$ and $\mathrm{THg}$ levels in soil ranged from $0.025-0.132 \mathrm{ng} / \mathrm{g}$ and $27.8-130.7 \mathrm{ng} / \mathrm{g}$, respectively. Compared to the spiked THg ( $5 \mathrm{mg} / \mathrm{kg}$ ), the background $\mathrm{Hg}$ levels could be ignored. $\mathrm{MeHg}$ concentrations in various soils on four stages are shown in Fig. 1. Soil MeHg levels on panicle initiation stage, heading stage, milk-ripe stage, and harvest stage ranged from 12.67 to $75.87 \mathrm{ng} / \mathrm{g}$, 8.03 to $91.37 \mathrm{ng} / \mathrm{g}, 8.15$ to $14.24 \mathrm{ng} / \mathrm{g}$, and 8.54 to $89.62 \mathrm{ng} / \mathrm{g}$, respectively.

Most soils were weakly alkaline or near neutral (6.9-8.0), except JX soil $(\mathrm{pH}=4.7)$. Clay contents $(15.5-45.7 \%)$ and soil organic contents (0.3-4.3\%) varied a lot in different soils (Table 1). The alteration of soil properties could have an important effect on $\mathrm{MeHg}$ production, which could cause the different concentrations of soil MeHg. For instance, soil organic matter could increase $\mathrm{MeHg}$ production [23] or inhibit the process of $\mathrm{Hg}$ methylation by binding strongly with $\mathrm{IHg}$ [24]. Also, it has been reported that clay could bind the IHg itself or form clay-OM to adsorb $\mathrm{IHg}$ [25], which could result in

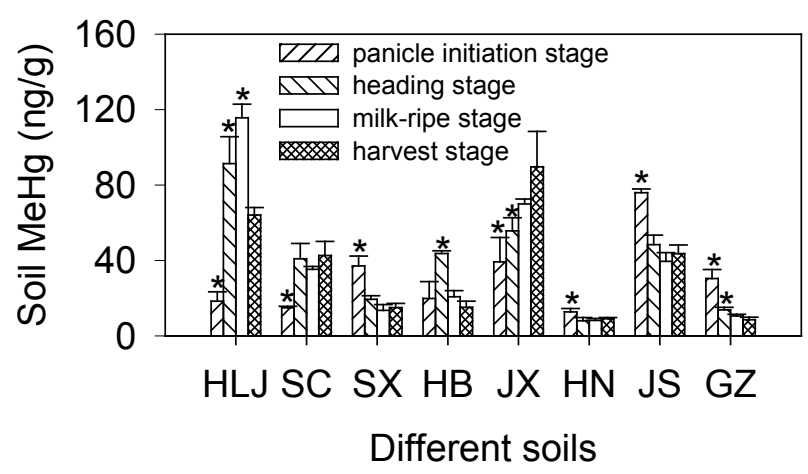

Fig. 1. MeHg concentrations in different soils at panicle initiation, heading, milk-ripe, and harvest stages. Mean \pm SD $(\mathrm{n}=3)$. Asterisk $(*)$ indicates significant difference from harvest stage ( $p<0.05$, one-way ANOVA).
Table 1. Soil properties and sampling inf ormation.

\begin{tabular}{|c|c|c|c|c|c|}
\hline Soil & $\begin{array}{l}\text { Sampling } \\
\text { site }\end{array}$ & $\begin{array}{c}\text { Sampling } \\
\text { depth }\end{array}$ & $\mathrm{pH}$ & $\begin{array}{c}\text { POC } \\
(\%)\end{array}$ & $\begin{array}{r}\text { Clay } \\
(\%)\end{array}$ \\
\hline HLJ & $\begin{array}{c}\text { Heilongjiang } \\
\text { Province }\end{array}$ & $0-30 \mathrm{~cm}$ & 7.5 & 2.0 & 37.6 \\
\hline $\mathrm{SC}$ & $\begin{array}{l}\text { Sichuan } \\
\text { Province }\end{array}$ & $0-30 \mathrm{~cm}$ & 7.8 & 1.6 & 41.9 \\
\hline SX & $\begin{array}{l}\text { Shanxi } \\
\text { Province }\end{array}$ & $0-30 \mathrm{~cm}$ & 8.0 & 0.7 & 41.4 \\
\hline HB & $\begin{array}{c}\text { Hubei } \\
\text { Province }\end{array}$ & $0-30 \mathrm{~cm}$ & 7.8 & 0.5 & 35.3 \\
\hline JX & $\begin{array}{c}\text { Jiangxi } \\
\text { Province }\end{array}$ & $0-30 \mathrm{~cm}$ & 4.7 & 0.3 & 15.5 \\
\hline $\mathrm{HN}$ & $\begin{array}{c}\text { Henan } \\
\text { Province }\end{array}$ & $0-30 \mathrm{~cm}$ & 7.7 & 0.9 & 30.2 \\
\hline JS & $\begin{array}{l}\text { Jiangsu } \\
\text { Province }\end{array}$ & $0-30 \mathrm{~cm}$ & 6.9 & 0.9 & 45.7 \\
\hline GZ & $\begin{array}{l}\text { Guizhou } \\
\text { Province }\end{array}$ & $0-30 \mathrm{~cm}$ & 7.9 & 4.3 & 41.3 \\
\hline
\end{tabular}

the decrease of bioavailable IHg in soil, thus inhibiting the production of $\mathrm{MeHg}$. Soil $\mathrm{pH}$ also plays a role in the process of $\mathrm{Hg}$ methylation [26]. For instance, low $\mathrm{pH}$ caused an increase of $\mathrm{MeHg}$ production [27]. Besides, the $\mathrm{MeHg}$ concentrations in soil were the common effect of the process of $\mathrm{Hg}$ methylation and $\mathrm{MeHg}$ demethylation. And soil properties including organic matter [28] and $\mathrm{pH}$ [29] could also alter the $\mathrm{MeHg}$ concentrations in soil by affecting the process of $\mathrm{MeHg}$ demethylation. We found that average soil $\mathrm{MeHg}$ concentrations were significant related to the soil properties by multiple regression analysis (averaged soil $\mathrm{MeHg}$ concentrations $=\mathrm{f}(\mathrm{pH}$, POC, clay), $p=0.006)$. Therefore, in this study properties variation of eight soils may affect variation in soil $\mathrm{MeHg}$ concentrations to different extents by affecting the process of $\mathrm{Hg}$ methylation and $\mathrm{MeHg}$ demethylation.

Meanwhile, the fluctuation of $\mathrm{MeHg}$ concentrations in four stages could be derived from the common effect of net production of $\mathrm{MeHg}$ in soil and the transportation of $\mathrm{MeHg}$ from soil to the rice plants. $\mathrm{MeHg}$ in soil was absorbed by roots and then transferred to the stem and leaf during the whole rice growth time [30]. This may imply that the difference of fluctuation of $\mathrm{MeHg}$ concentrations among eight soils was because the variation was controlled by the combined effects of soil properties and the $\mathrm{MeHg}$ migration capability of rice plants. And we suspected that rice growth was quite different in eight treatments since the biomass per pot of rice plant varied, ranging from 21.8 to $81.6 \mathrm{~g}$, which may lead to the change of $\mathrm{MeHg}$ migration capability of rice plants.

\section{Bioaccumulation of Inorganic Mercury and $\mathrm{MeHg}$ in Rice Plants}

IHg concentrations in leaves are shown in Fig. 2. $\mathrm{IHg}$ concentrations in leaves were quite different, but the $\mathrm{IHg}$ 


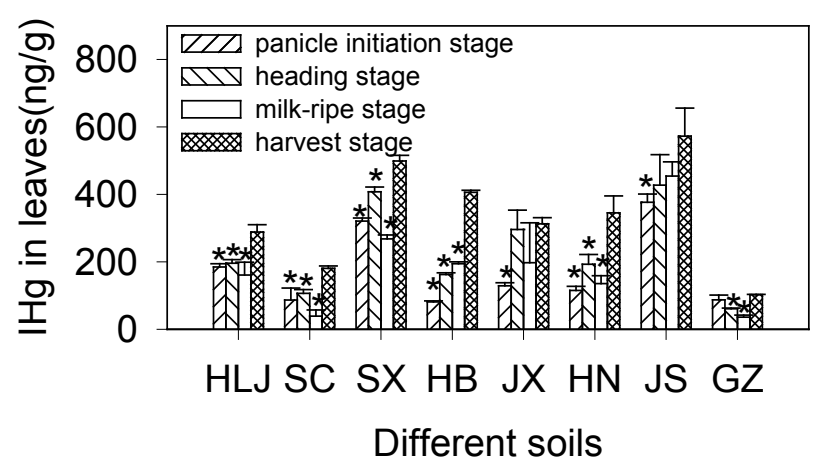

Fig. 2. IHg concentrations in rice leaves at panicle initiation, heading, milk-ripe, and harvest stages. Mean \pm SD $(n=3)$. Asterisk $(*)$ indicates significant difference from harvest stage $(p<0.05$, one-way ANOVA).

concentrations of leaves for all the treatments in harvest stage were the highest compared to that in other stages. The increase of $\mathrm{IHg}$ concentrations of leaves in this stage could be due to the fact that little or no IHg in rice leaves could be transferred to rice grains in the harvest stage. Similarly, Meng et al. found that accumulated $\mathrm{IHg}$ in aboveground parts of rice plants cannot be transported to seeds [12]. And the decrease of IHg concentrations in leaves in some stage could be mainly due to the emissions of $\mathrm{IHg}$ in leaves to the air through leaf pores or the translocation of $\mathrm{IHg}$ from leaves to the stalk during the rice-growing season [13].

$\mathrm{MeHg}$ concentrations and $\mathrm{MeHg}$ rates of leaves $(\%$, $\mathrm{MeHg}$ concentrations in leaves / $\mathrm{THg}$ concentrations
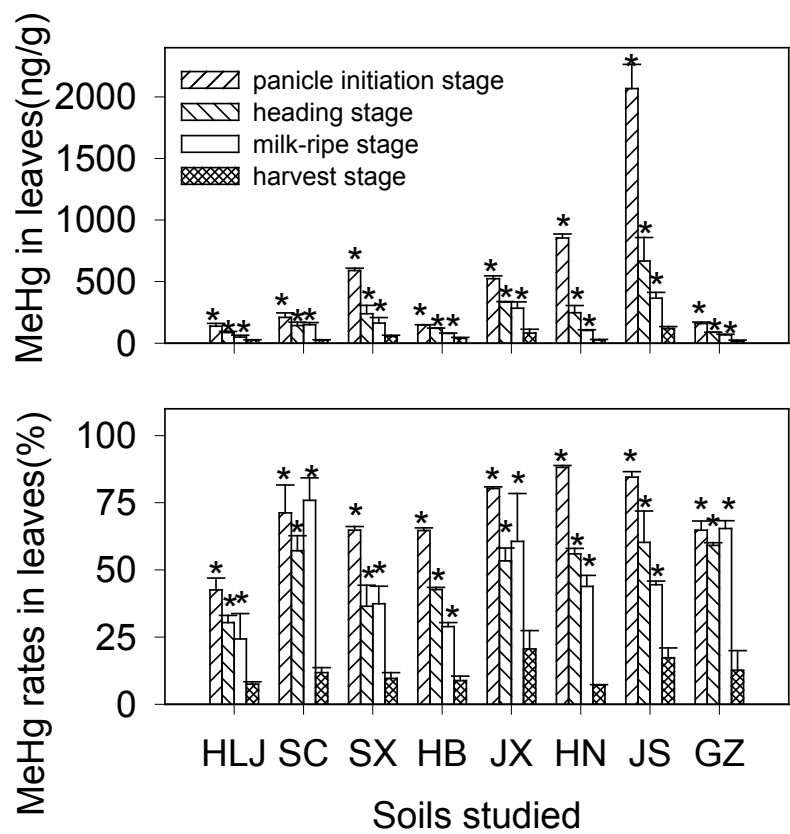

Fig. 3. MeHg concentrations in rice leaves at panicle initiation, heading, milk-ripe, and harvest stages (upper panel); $\mathrm{MeHg}$ rates in rice leaves at different stages (lower panel). Mean \pm SD $(\mathrm{n}=3)$. Asterisk $(*)$ indicates significant difference from harvest stage ( $p<0.05$, one-way ANOVA). in leaves) are shown in Fig. 3. Large variations in $\mathrm{MeHg}$ concentrations $(137.46-2,067.55 \mathrm{ng} / \mathrm{g}$ for panicle initiation stage, 85.51-666.84 ng/g for heading stage, 49.86-365.39 ng/g for milk-ripe stage, $15.33-117.91 \mathrm{ng} / \mathrm{g}$ for harvest stage), and $\mathrm{MeHg}$ rates (42.53-88.15\% for panicle initiation stage, 30.36-60.25\% for heading stage, $24.31-75.88 \%$ for milk-ripe stage, $7.08-20.55 \%$ for harvest stage) in leaves among different soils at different stages were observed. Generally speaking, $\mathrm{MeHg}$ concentrations and $\mathrm{MeHg}$ rates in leaves decreased (73.58 to $96.91 \%$ and 74.41 to $91.97 \%$ ) with time for all soil, respectively. And the gradually decreasing $\mathrm{MeHg}$ concentrations and $\mathrm{MeHg}$ rates of leaves during the rice-growing season may indicate that most $\mathrm{MeHg}$ was translocated from leaves to the rice grains in the harvest stage.

In the harvest stage, the $\mathrm{IHg}$ and $\mathrm{MeHg}$ concentration in leaves ranged from 102.35 to $572.82 \mathrm{ng} / \mathrm{g}$ and 15.33 to $117.91 \mathrm{ng} / \mathrm{g}$, respectively. After harvesting, rice straw and leaves were often buried into soils in order to increase soil organic matter in rice paddy fields [16]. Therefore, the mercury-contaminated rice leaves may result in the input of 'new mercury' into soils, leading to $\mathrm{Hg}$ pollution circulation in the rice paddy system.

$\mathrm{MeHg}$ concentrations extracted by $\left(\mathrm{NH}_{4}\right)_{2} \mathrm{~S}_{2} \mathrm{O}_{3}$ and $\mathrm{MeHg}$ extraction rates (\%, $\mathrm{MeHg}$ concentrations extracted from soil / soil $\mathrm{MeHg}$ concentrations) are shown in Fig. 4. Significant relationships between rice grain $\mathrm{MeHg}$ levels and $\left(\mathrm{NH}_{4}\right)_{2} \mathrm{~S}_{2} \mathrm{O}_{3}$-extracted $\mathrm{MeHg}$ of soil have been reported, and $\left(\mathrm{NH}_{4}\right)_{2} \mathrm{~S}_{2} \mathrm{O}_{3}$ extraction may mimic $\mathrm{MeHg}$ uptake by roots and its accumulation in rice plants [17]. Therefore, $\mathrm{MeHg}$ concentrations extracted from soils were used to indicate potential
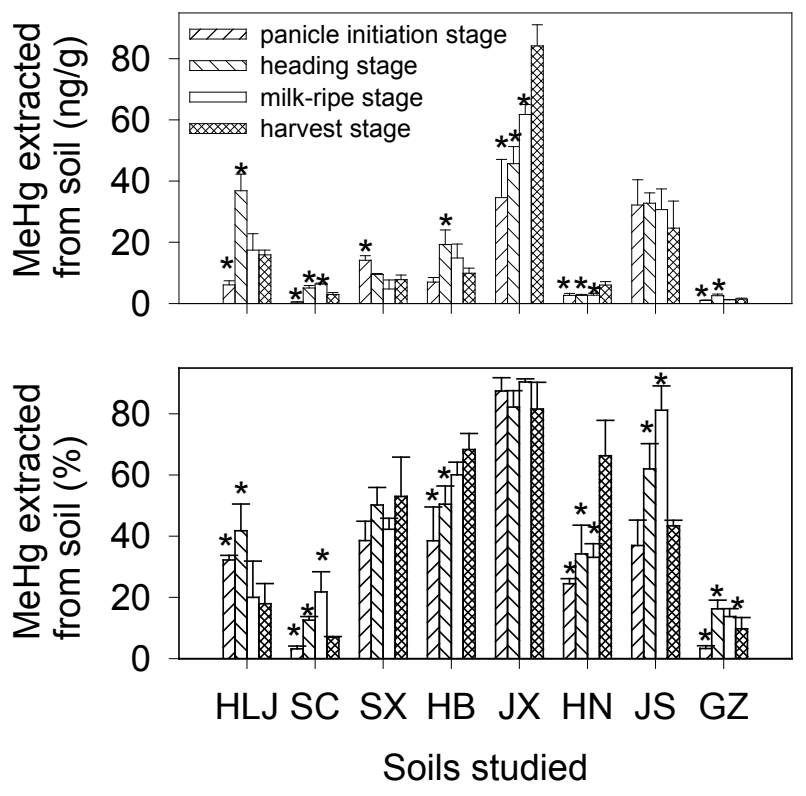

Fig.4. Concentrations of $\mathrm{MeHg}$ extracted by $\left(\mathrm{NH}_{4}\right)_{2} \mathrm{~S}_{2} \mathrm{O}_{3}$ from different soils (upper panel), as well as $\mathrm{MeHg}$ extraction rates (lower panel) at panicle initiation, heading, milk-ripe, and harvest stages. Mean $\pm \mathrm{SD}(\mathrm{n}=3)$. Asterisk $(*)$ indicates significant difference from harvest stage ( $p<0.05$, one-way ANOVA). 
$\mathrm{MeHg}$ bioaccumulation, and the $\mathrm{MeHg}$ extraction rate was used to indicate phytoavailable $\mathrm{MeHg}$ in this study. Unlike the $\mathrm{MeHg}$ concentrations in leaves, the $\mathrm{MeHg}$ concentrations extracted from soils and $\mathrm{MeHg}$ extraction rates by $\left(\mathrm{NH}_{4}\right)_{2} \mathrm{~S}_{2} \mathrm{O}_{3}$ fluctuated during the whole rice growth season, which may indicate the $\mathrm{MeHg}$ potential phytoavailable and bioaccumulation changing all the time. This could be mainly due to the variance of $\mathrm{MeHg}$ bioavailability in soil as affected by soil properties and rice plant physiology conditions, which varied in eight treatments. And the $\mathrm{MeHg}$ concentrations extracted from soils varied from the $\mathrm{MeHg}$ concentrations in leaves, suggesting that $\mathrm{MeHg}$ concentrations in leaves could not indicate the bioaccumulation of $\mathrm{MeHg}$ in rice grains. This could be attributed to the fact that the proportion of $\mathrm{MeHg}$ in leaves transported to the rice grain was different among different treatments.

\section{Migration of $\mathrm{MeHg}$ in the Rice Plants}

$\mathrm{MeHg}$ migration rates $(\%, \mathrm{MeHg}$ concentration in leaves / $\mathrm{MeHg}$ concentration in soil) are shown in Fig. 5, which was used to indicate the $\mathrm{MeHg}$ migration capability of $\mathrm{MeHg}$ from soil to rice plants. Compared to the $\mathrm{MeHg}$ migration rates in panicle initiation stages, its migration rates in harvest stage significantly decreased $(61.85-95.95 \%)$ for all the treatments, indicating that the translocation of $\mathrm{MeHg}$ from soil to rice plant continuously declined with the growth of rice plants. This may be because the bioavailability of $\mathrm{MeHg}$ generated from the $\mathrm{IHg}$ decreased with time. It was been documented that mobility and bioavailability of mercury may decrease with time, which has been mentioned as the aging effect [31]. The decrease in $\mathrm{MeHg}$ bioavailability may be attributed to the transfer of $\mathrm{MeHg}$ to stronger binding sites in soils [31]. We suspected that the decrease in $\mathrm{MeHg}$ migration rates in leaves may also be attributed to the translocation of $\mathrm{MeHg}$ to the rice grains in harvest time. It has been reported that most $\mathrm{MeHg}$ accumulates in the rice grain

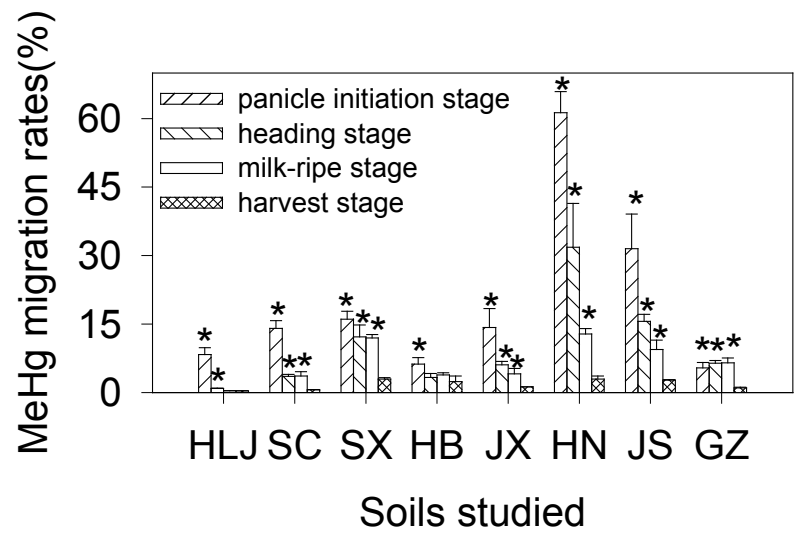

Fig. 5. MeHg migration rates at panicle initiation, heading, milkripe, and harvest stages. Mean $\pm \operatorname{SD}(n=3)$. Asterisk $(*)$ indicates significant difference from harvest stage $(p<0.05$, one-way ANOVA). compared to other rice plant tissues [32-33]. And $\mathrm{MeHg}$ in soil was first absorbed by roots and then transferred to the stem and leaf, and finally translocated to the grain during the harvest period [34].

\section{Conclusion and Implications}

In conclusion, the fluctuation of $\mathrm{MeHg}$ concentrations in soil could be because $\mathrm{MeHg}$ production in soil was affect by the two processes ( $\mathrm{Hg}$ methylation and $\mathrm{MeHg}$ demethylation), and $\mathrm{Hg}$ methylation and $\mathrm{MeHg}$ demethylation were dynamic during the whole rice growth season. Meanwhile, the translocation of $\mathrm{MeHg}$ from soil to the rice plants could also lead to the variation of $\mathrm{MeHg}$ concentrations in soil. Our study also reported that the limit or no $\mathrm{IHg}$ was migrated to the rice grains in harvest stage, since the IHg concentrations in leaves were the highest in the harvest stage compared to that in other stages.

Based on our results, $\mathrm{MeHg}$ concentrations in leaves could not be used to indicate $\mathrm{MeHg}$ bioaccumulation in rice grain, for there was a difference between the $\mathrm{MeHg}$ concentrations in leaves and the $\mathrm{MeHg}$ concentrations extracted from soils by $\left(\mathrm{NH}_{4}\right)_{2} \mathrm{~S}_{2} \mathrm{O}_{3}$, which could potentially simulate $\mathrm{MeHg}$ accumulation in rice plants. We suspected that this could be attributed to the different proportions of $\mathrm{MeHg}$ translocation from leaves to rice grains. More studies are needed to fully understand the mechanism of $\mathrm{MeHg}$ migration in the rice plants.

In this study, the decrease of $\mathrm{MeHg}$ transferred capability from soil to leaves in the harvest stage could be due to the lower bioavailability of $\mathrm{MeHg}$ in soil. Another explanation of the lower $\mathrm{MeHg}$ transferred capability to leaves could be the $\mathrm{MeHg}$ migration from leaves to rice grains, which could be due to the preferential partitioning of $\mathrm{MeHg}$ into rice grains.

In view of the scarcity of arable lands in China, large areas of mercury-contaminated lands are still being farmed, e.g., for rice cultivation. Therefore, it is of significance to study the $\mathrm{MeHg}$ and $\mathrm{IHg}$ bioaccumulation and migration mechanism in the rice plant. It should be noted that we preliminarily focused on the soil that was newly contaminated by mercury. Further studies are necessary on mercury contacting soil in the long term to investigate the mechanism of the difference of bioaccumulation and migration between $\mathrm{MeHg}$ and $\mathrm{IHg}$.

\section{Acknowledgements}

This work was funded by Shaanxi Province Key Program for Science Innovation Team (No. 2016KCT-23).

\section{References}

1. XINBIN F., PING L., GUANGLE Q., SHAOFENG W., GUANGHUI L., LIHAI S., BO M., HONGMEI J., WEIYANG B., ZHONGGEN L. Human exposure to 
methylmercury through rice intake in mercury mining areas, Guizhou province, China. Environmental Science \& Technology. 42 (1), 326, 2008.

2. ZHANG H., FENG X., LARSSEN T., QIU G., VOGT R.D. In inland China, rice, rather than fish, is the major pathway for methylmercury exposure. Environmental Health Perspectives. 118 (9), 1183, 2010.

3. MILENA H., NATASA N., VESNA F., VESNA J., MARTINA L., SONJA L., RADOJKO J., INGRID F., QU L., JADRAN F. Total mercury, methylmercury and selenium in mercury polluted areas in the province Guizhou, China. Science of the Total Environment. 304 (1-3), 231, 2003.

4. FENG X. Mercury Pollution in the Environment. Progress in Chemistry. 21 (0203), 436, 2009.

5. GUANGLE Q., XINBIN F., PING L., SHAOFENG W., GUANGHUI L., LIHAI S., XUEWU F. Methylmercury accumulation in rice (Oryza sativa L.) grown at abandoned mercury mines in Guizhou, China. Journal of Agricultural \& Food Chemistry. 56 (7), 2465, 2008.

6. ROTHENBERG S.E., FENG X. Mercury cycling in a flooded rice paddy. Journal of Geophysical Research Biogeosciences. 117, 184, 2012

7. MENG M., LI B., SHAO J.J., WANG T., HE B., SHI J.B., YE Z.H., JIANG G.B. Accumulation of total mercury and methylmercury in rice plants collected from different mining areas in China. Environmental Pollution. 184 (1), 179, 2014.

8. QIU G., FENG X., WANG S., SHANG L. Mercury and methylmercury in riparian soil, sediments, mine-waste calcines, and moss from abandoned $\mathrm{Hg}$ mines in east Guizhou province, southwestern China. Applied Geochemistry. 20 (3), 627, 2005.

9. BO M., XINBIN F., GUANGLE Q., PENG L., PING L., CHUNXIAO C., LIHAI S. The process of methylmercury accumulation in rice (Oryza sativa L.). Environmental Science \& Technology. 45 (7), 2711, 2011.

10. MARIA G., YAODONG W., CLARA N. Absence of $\mathrm{Hg}$ transpiration by shoot after $\mathrm{Hg}$ uptake by roots of six terrestrial plant species. Environmental Pollution. 134 (2), 201, 2005.

11. LODENIUS M., TULISALO E., SOLTANPOURGARGARI A. Exchange of mercury between atmosphere and vegetation under contaminated conditions. Science of the Total Environment. 304, 169, 2003.

12. MENG B., FENG X., QIU G., WANG D., LIANG P., LI P., SHANG L. Inorganic mercury accumulation in rice (Oryza sativa L.). Environmental Toxicology \& Chemistry. 31 (9), 2093, 2012

13. BO M., XINBIN F., GUANGLE Q., YONG C., DINGYONG W., PING L., LIHAI S., JONAS S. Distribution patterns of inorganic mercury and methylmercury in tissues of rice (Oryza sativa L.) plants and possible bioaccumulation pathways. Journal of Agricultural \& Food Chemistry. 58 (8), 4951, 2010.

14. WINDHAMMYERS L., FLECK J., EAGLESSMITH C., ACKERMAN J. Mercury methylation, export and bioaccumulation in rice agriculture - model results from comparative and experimental studies in 3 regions of the California Delta, USA. In: AGU Fall Meeting Abstracts. 2013.

15. HUA Z., XINBIN F., THORJ?RN L., LIHAI S., PING L. Bioaccumulation of methylmercury versus inorganic mercury in rice (Oryza sativa L.) grain. Environmental Science \& Technology. 44 (12), 4499, 2010.

16. TIROL-PADRE A., TSUCHIYA K., INUBUSHI K., LADHA J.K. Enhancing Soil Quality through Residue Management in a Rice-Wheat System in Fukuoka, Japan.
Soil Science \& Plant Nutrition. 51 (6), 849, 2005.

17. ZHU D.W., ZHONG H., ZENG Q.L., YIN Y. Prediction of methylmercury accumulation in rice grains by chemical extraction methods. Environmental Pollution. 199c, 1, 2015.

18. PENG X., LIU F., WANG W.X., YE Z. Reducing total mercury and methylmercury accumulation in rice grains through water management and deliberate selection of rice cultivars. Environmental Pollution. 162 (162), 202, 2012.

19. OKKENHAUG G., ZHU Y.G., HE J., LI X., LUO L., MULDER J. Antimony ( $\mathrm{Sb}$ ) and arsenic (As) in Sb mining impacted paddy soil from Xikuangshan, China: differences in mechanisms controlling soil sequestration and uptake in rice. Environmental Science \& Technology. 46 (6), 3155, 2012.

20. HUAN Z., WEN-XIONG W. Controls of dissolved organic matter and chloride on mercury uptake by a marine diatom. Environmental Science \& Technology. 43 (23), 8998, 2009.

21. BLOOM N. Determination of Picogram Levels of Methylmercury by Aqueous Phase Ethylation, Followed by Cryogenic Gas Chromatography with Cold Vapour Atomic Fluorescence Detection. Canadian Journal of Fisheries \& Aquatic Sciences. 46 (7), 1131, 1989.

22. AND C.G., FISHER N.S. Bioavailability of SedimentBound Methyl and Inorganic Mercury to a Marine Bivalve. Environmental Science \& Technology. 31 (4), 1997.

23. ULLRICH S.M., TANTON T.W., ABDRASHITOVA S.A. Mercury in the aquatic environment: a review of factors affecting methylation. Critical Reviews in Environmental Science \& Technology. 31 (3), 241, 2001.

24. MISKIMMIN B.M., RUDD J.W.M., KELLY C.A. Influence of Dissolved Organic Carbon, $\mathrm{pH}$, and Microbial Respiration Rates on Mercury Methylation and Demethylation in Lake Water. Canadian Journal of Fisheries \& Aquatic Sciences. 4 (49), 17, 2006.

25. ZHU D., ZHONG H. Potential bioavailability of mercury in humus-coated clay minerals. Journal of Environmental Sciences. 36 (10), 48, 2015.

26. ROTHENBERG S.E., FENG X., ZHOU W., MING T., JIN B., YOU J. Environment and genotype controls on mercury accumulation in rice (Oryza sativa L.) cultivated along a contamination gradient in Guizhou, China. Science of the Total Environment. 426 (2), 272, 2012.

27. STEFFAN R.J., KORTHALS E.T., WINFREY M.R. Effects of acidification on mercury methylation, demethylation, and volatilization in sediments from an acid-susceptible lake. Applied \& Environmental Microbiology. 54 (8), 2003, 1988.

28. MATILAINEN T., VERTA M. Mercury methylation and demethylation in aerobic surface waters. Canadian Journal of Fisheries \& Aquatic Sciences. 52 (8), 1597, 2011.

29. RAMIAL P.S., RUDD J.W.M., FURUTAM A., XUN L. The Effect of $\mathrm{pH}$ on Methyl Mercury Production and Decomposition in Lake Sediments. Canadian Journal of Fisheries \& Aquatic Sciences. 42 (4), 685, 1985.

30. ZHOU J., LIU H., DU B., SHANG L., YANG J., WANG Y. Influence of soil mercury concentration and fraction on bioaccumulation process of inorganic mercury and methylmercury in rice (Oryza sativa L.). Environmental Science \& Pollution Research International. 22 (8), $1,2015$.

31. MA L., ZHONG H., WU Y.G. Effects of Metal-Soil Contact Time on the Extraction of Mercury from Soils. Bulletin of Environmental Contamination \& Toxicology. 94 (3), 399, 2015.

32. ROTHENBERG S.E., WINDHAM-MYERS L., CRESWELL J.E. Rice methylmercury exposure and mitigation. A comprehensive review. Environmental 
Research. 133 (2), 407, 2014.

33. WINDHAM-MYERS L., FLECK J.A., ACKERMAN J.T., MARVIN-DIPASQUALE M., STRICKER C.A., HEIM W.A., BACHAND P.A.M., EAGLES-SMITH C.A., GILL G., STEPHENSON M. Mercury cycling in agricultural and managed wetlands: a synthesis of methylmercury production, hydrologic export, and bioaccumulation from an integrated field study. Science of the Total Environment. 484
(24), 221, 2014.

34. ROTHENBERG S.E., FENG X., DONG B., SHANG L., YIN R., YUAN X. Characterization of mercury species in brown and white rice (Oryza sativa L.) grown in watersaving paddies. Environmental Pollution. 159 (5), 1283, 2011. 